\title{
CHANGE OF QUALITY OF WAFER PRODUCTS WITH SYNBIOTIC DURING STORAGE
}

\author{
H. Korkach, T. Lebedenko, N. Karatsuba \\ Odessa National Academy of Food Technologies
}

\begin{tabular}{l}
\multicolumn{1}{c}{ Key words: } \\
Fat filling \\
Dysbiosis \\
Synbiotic products \\
Waffles \\
Quality \\
Shelf life \\
\hline
\end{tabular}

Article history:

Received 12.09.2018

Received in revised form

03.10.2018

Accepted 24.10.2018

Corresponding author:

H. Korkach

E-mail:

npnuht@ukr.net

\begin{abstract}
Confectionery products are in great demand among different sectors of the population, especially children and young people, both in Ukraine and in other countries. This group of products can be considered to be a convenient carrier of vital nutrients, the lack of which in the diet of Ukrainian population is a serious problem. Therefore, the industry faces the task of developing and introducing products with not only high nutritional value and good taste but beneficial physiological effects as well. A promising trend is the development of products aimed at prevention and treatment of various types of diseases. These types of products include, first of all, products for people with intestinal microflora disorder.

In this work the market of functional confectionery products has been analyzed. The importance and necessity of developing wafer products with synbiotics has been presented and their selection and recipe composition have been substantiated. The change in the consumer characteristics of finished products in the process of storage has been determined. Several quality parameters of finished products (changes in peroxide value of fatty fillings, microbiological and sensory characteristics of finished products) have been researched. The dynamics of accumulating the primary products of fat oxidation has been investigated and it has been established that the peroxide number of wafer samples was 3.4 times less than the control at the end of the storage period.

In order to determine the influence of synbiotics on the shelf life of wafers, their microbiological parameters have been determined, since the number of mesophilic aerobic and facultative anaerobic microorganisms, coliform bacteria, mold fungi, and yeast characterizes the safety of the wafer products for consumption. The results of the sensory analysis showed that test samples of wafers with synbiotic had favorably different taste parameters and structure compared to control.
\end{abstract}

DOI: $10.24263 / 2225-2924-2018-24-5-20$ 


\title{
ЗМІНА ЯКОСТІ ВАФЕЛЬНИХ ВИРОБІВ ІЗ СИНБІОТИКОМ ПРИ ЗБЕРІГАННІ
}

\author{
Г.В. Коркач, Т.С. Лебеденко, Н.Л. Карацуба \\ Одеська національна академія харчових технологій
}

Кондитерські вироби користуються великим попитом у різних верств населення, особливо дітей $і$ молоді. Ця група продуктів може розглядатися як зручний носій життєво важливих поживних речовин, нестача яких у раціоні населення України є серйозною проблемою. Тому перед галуззю стоїть завдання розроблення $і$ впровадження у виробництво виробів, які б, крім харчової иінності і смакових переваг, володіли фізіологічним впливом. Перспективним напрямом залишається розробка продуктів, спрямованих на профілактику та лікування різних видів захворювання. До таких видів продуктів можна віднести передусім вироби для людей з порушенням кишкової мікрофлори.

У статті проведено дослідження ринку функиіональних кондитерських виробів. Обтрунтовано актуальність $і$ потребу в розробиі вафельних виробів з синбіотиками, їх вибір і розроблено рецептурну композицію. Проведено комплекс досліджень з визначення зміни споживчих характеристик готових виробів у прочесі зберігання. Якість готових виробів визначали за кількома параметрами: за зміною перекисного числа жирової начинки, мікробіологічним та органолептичним показникам готових виробів. Досліджено динаміку накопичення первинних продуктів окислення жиру і встановлено, що в кінці строку зберігання перекисне число у дослідних зразків вафель було меншим за контроль у 3,4 раза.

Для визначення впливу синбіотику на термін придатності вафель визначали мікробіологічні показники: кількість мезофільних аеробних і факультативно-анаеробних мікроорганізмів, бактерій групи кишкової палички, плісняви грибів та дріжджів, які характеризують безпечність вафельних виробів до споживання. Результати сенсорного аналізу показали, що дослідні зразки вафель із синбіотиком вигідно відрізняються від контролю за смаковими показниками та структурою.

Ключові слова: жирова начинка, дисбактеріоз, продукти-синбіотики, вафлі, якість, термін зберігання.

Постановка проблеми. В наш час загальновизнаною цінністю світове співтовариство вважає індивідуальне та громадське здоров'я. Здоров'я нації розглядається як показник цивілізованості держави, що відображає соціально-економічний стан суспільства.

Проблеми «харчування і здоров'я» та «харчування i хвороби» тісно взаємопов'язані. Нераціональне харчування $є$ визначальним у виникненні та розвитку таких факторів ризику, як надлишкова маса тіла, артеріальна гіпертензія, цукровий діабет, захворювання шлунково-кишкового тракту. Людина здорова та відносно незалежна від змін умов навколишнього середовища до 
тих пір, поки здатна підтримувати стабільність внутрішнього середовища організму.

У сучасному світі у зв'язку з погіршенням екологічної обстановки, підвищенням психічно-нервових навантажень, емоційної нестійкості та все більш широким застосуванням антибіотиків спостерігається порушення стабільності складу мікрофлори кишечника людини, що призводить до появи дисбактеріозу. У зв'язку з цим триває активний пошук оптимальних засобів, спрямованих на профілактику виникнення дисбактеріозу. Цим зумовлена поява на ринку продуктів-синбіотиків. Ефективність синбіотиків заснована на синергізмі пробіотиків і пребіотиків, за рахунок якого не тільки імплантуються мікроорганізми в шлунково-кишковий тракт людини, але й стимулюються зростання і розвиток його власної мікрофлори.

Кондитерські вироби представляють собою групу харчових продуктів широкого асортименту, які значно відрізняються за ціною, складом і споживчими характеристиками. Більшу половину ринку кондитерських виробів в Україні займають борошняні кондитерські вироби (БКВ). Вони користуються регулярним стійким попитом у споживачів завдяки високим смаковим якостям, ціновій доступності, зручності споживання, а також традиціям у харчуванні українців. БКВ істотно доповнюють раціон харчування різних вікових груп населення, особливо дітей і молоді. Однак склад БКВ незбалансований, вони мають низьку харчову і високу енергетичну цінність (калорійність), містять велику кількість жирів і вуглеводів при незначному вмісті незамінних інгредієнтів, мікро- і макронутрієнтів та функціонально-фізіологічних речовин.

Враховуючи доступність і популярність БКВ у населення України, формування їх асортименту з урахуванням функціональної спрямованості $\epsilon$ актуальним напрямком впливу на раціон харчування людини.

Аналіз останніх досліджень і публікацій. Доцільність збагачення БКВ фізіологічно функціональними інгредієнтами, що дають змогу надавати їм різну функціональну спрямованість і покращувати споживчі властивості, відзначається в публікаціях як зарубіжних вчених, так і українських вчених.

Наукові основи, технології і рецептури БКВ функціонального призначення вивчено в [1], з метою економії дефіцитних видів сировини, зниження цукроємності, створення виробів лікувально-профілактичного призначення, дитячого асортименту, виробів 3 більш тривалим терміном зберігання вдосконалено структуру асортименту цукрового печива [2] та пряничних виробів і крекерів [3].

Велика кількість праць присвячена розробці й удосконаленню технології вафельних виробів з функціональними властивостями, призначених для здорового харчування [4-8].

У праці Т.М. Лозової [9] досліджена проблема підвищення харчової і біологічної цінності вафель із жировими начинками, рецептури яких включають нетрадиційну сировину.

Проведені дослідження і встановлено, що оптимальна кількість інуліну і олігофруктози при виробництві вафельних виробів становить $10 \%$ до маси начинки, що обумовлює їх функціональну спрямованість, а висока технологічність і здатність замінювати частину жиру й цукру забезпечує продуктам високі споживчі властивості [10]. 
В [11] проведені дослідження зі створенню вафель функціональної спрямованості з використанням апельсинових харчових волокон. Розроблений вид виробів необхідний для людей, які страждають ожирінням, цукровим діабетом, атеросклерозом, з порушенням нормальної кишкової мікрофлори i іншими захворюваннями.

У статті [12] підкреслюється підвищений інтерес споживачів до функціонального печива, збагаченого насінням льону. Печиво з льняним насінням може бути джерелом омега-3 жирних кислот у щоденному раціоні. Виявлено потенційний портрет споживачів: літні жінки 3 високим рівнем поінформованості про продукти здорового харчування, а також люди, зацікавлені в правильному харчуванні.

Проте проблема комплексного забезпечення якості готових виробів, їх збалансованості за харчовою цінністю, надання функціональних властивостей гостро стоїть перед науковцями кондитерської галузі. В умовах сучасного ринку важливу роль відіграє створення конкурентоспроможної продукції. Такі вироби повинні володіти високими органолептичними характеристиками та мати тривалі терміни придатності.

Метою дослідження $є$ вивчення впливу синбіотичного комплексу на зміну якісних показників вафельних виробів у процесі зберігання.

Викладення основних результатів досліджень. Проаналізувавши ринок БКВ, прийшли до висновку, що найбільш затребуваною продукцією на українському ринку борошняних солодощів залишається продукція сегменту «Печиво солодке й вафлі». Тому як кондитерський виріб для введення синбіотичної добавки були запропоновані вафлі із жировою начинкою.

Попередніми дослідженнями було обгрунтовано вибір функціональних інгредієнтів для створення синбіотичного комплексу, який складається з імобілізованих біфідобактерій та інуліну, встановлено стадію внесення та масову частку добавки [13;14].

Одним із визначальних факторів, що впливають на обсяги виробництва $\mathrm{i}$ продажу продукції, є термін придатності. Це період, протягом якого виріб залишається безпечним. Збереженість продукції залежить від якості вихідної сировини, правильності проведення технологічного процесу, санітарно-гігієнічних умов виробництва, пакування i, звичайно ж, від дотримання умов зберігання.

Для оцінки якості розроблених вафельних виробів проводили комплексну оцінку їх споживчих властивостей. Результати сенсорного аналізу показали, що вони вигідно відрізняються від контролю за смаковими показниками, оскільки мають начинку більш ніжної консистенції. При цьому сторонні присмаки відсутні.

Органолептичні показники розробленого виду вафельних виробів 3 синбіотичним комплексом наведені в табл. 1.

Умови розвитку ринкової економіки в нашій країні диктують необхідність враховувати при проведенні досліджень не тільки фізіологічні потреби населення, але й конкурентоспроможність пропонованих виробів. При виборі продуктів споживач керується насамперед органолептичними показниками. 3 
метою визначення органолептичних показників, що характеризують споживчу привабливість продукту, був застосований системний підхід. Ознаки (дескриптори), за якими оцінювались вироби, були розроблені за результатами обговорення членами дегустаційної комісії

\section{Таблиия 1. Органолептичні показники якості вафель}

\begin{tabular}{|c|c|c|}
\hline $\begin{array}{c}\text { Найменування } \\
\text { показника }\end{array}$ & Контроль & Дослідний зразок «Перлинка» \\
\hline Смак & $\begin{array}{l}\text { Солодкий, без стороннього } \\
\text { присмаку }\end{array}$ & $\begin{array}{c}\text { Менш солодкий, без жирового } \\
\text { присмаку, хрусткий }\end{array}$ \\
\hline Запах & \begin{tabular}{|c|} 
Властивий цьому виду виробу, без \\
стороннього запаху і присмаків
\end{tabular} & $\begin{array}{c}\text { Властивий цьому виду виробу, без } \\
\text { стороннього запаху і присмаків. } \\
\text { Вафельні вироби відрізняються } \\
\text { приємним ароматом }\end{array}$ \\
\hline Колір & \multicolumn{2}{|c|}{$\begin{array}{c}\text { Колір листа - світло-жовтий, в розрізі - комбінований. Колір } \\
\text { начинки - однорідний, білий }\end{array}$} \\
\hline Будова у розломі & \multicolumn{2}{|c|}{$\begin{array}{c}\text { Вафельні листи рівномірно пропечені, з розвинутою пористістю, } \\
\text { володіють хрусткими властивостями, } \\
\text { начинка рівномірно розподілена }\end{array}$} \\
\hline $\begin{array}{l}\text { Зовнішній вигляд, } \\
\text { поверхня }\end{array}$ & \multicolumn{2}{|c|}{$\begin{array}{c}\text { Поверхня з чітким малюнком, з рівним обрізом, без підтікань. } \\
\text { Начинка у вафлях не виступає за краї }\end{array}$} \\
\hline $\begin{array}{c}\text { Консистенція } \\
\text { начинки }\end{array}$ & $\begin{array}{c}\text { Начинка неоднорідної } \\
\text { консистенції без грудочок, але } \\
\text { інколи трапляються грудочки, } \\
\text { масляниста, міцно тримає } \\
\text { вафельні листи }\end{array}$ & $\begin{array}{c}\text { Начинка однорідної ніжної } \\
\text { консистенції, легко тане, без } \\
\text { грудочок і крупинок. У готовому } \\
\text { виробі - щільна, міцно тримає } \\
\text { вафельні листи }\end{array}$ \\
\hline
\end{tabular}

Експерти одноголосно на перше місце за значущістю поставили смак борошняних кондитерських виробів, на друге місце - запах. За отриманим розподілом рангів було встановлено, що найбільш важливою категорією споживчої привабливості і, відповідно, критерієм оцінки вафельних виробів є смак.

На підставі результатів дегустацій побудували профілограму смаку виробів.

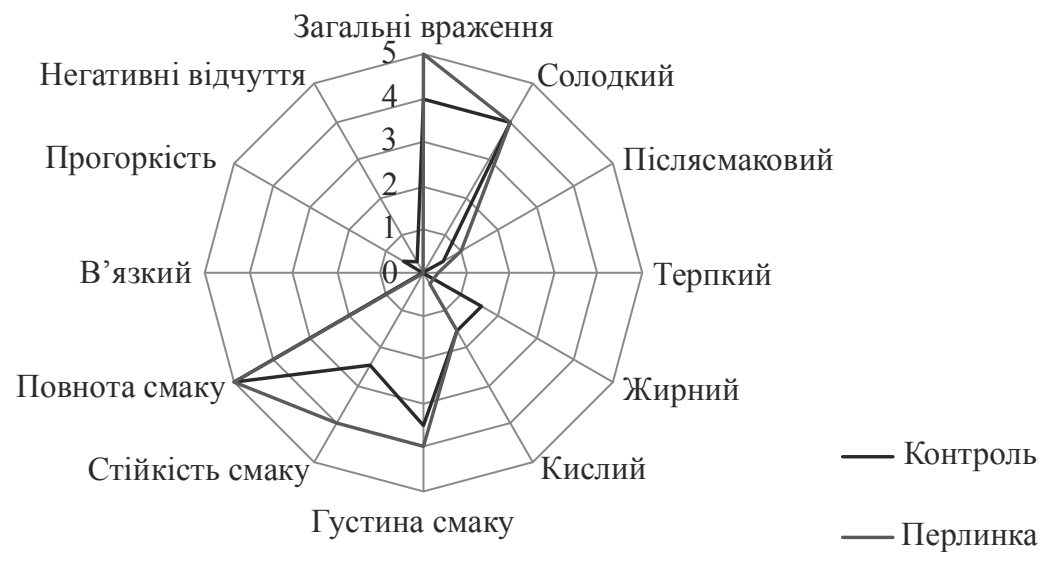

Рис. Профілограма смаку вафель 
Для розроблених вафельних виробів важливо, щоб вони зберігали свої властивості протягом усього терміну придатності. Тому проводили дослідження з визначення показників якості вафельних виробів у процесі зберігання.

Вафельні вироби, згідно з ДСТУ 4033-2001 «Вафлі. Загальні технічні умови», повинні зберігатись при температурі навколишнього середовища $(18 \pm 3)^{\circ} \mathrm{C}$ і відносній вологості повітря 65-70\%. Строк зберігання вафель із жировою начинкою, виготовлених на основі рослинних твердих жирів 3 тривалими термінами зберігання, складає три місяці.

Якість готових виробів визначали за кількома параметрами: за зміною перекисного числа жирової начинки, мікробіологічними та органолептичними показниками готових виробів.

Оскільки найбільш уразлива до псування жирова фракція вафельних виробів, було визначено зміну перекисного числа - досліджено динаміку накопичення первинних продуктів окислення жиру (табл. 2).

Таблиия 2. Зміна перекисного числа в процесі зберігання

\begin{tabular}{|c|c|c|}
\hline Час зберігання, діб & Контроль & Вафлі «Перлинка» \\
\hline 0 & 0,041 & 0,017 \\
\hline 15 & 0,051 & 0,017 \\
\hline 30 & 0,058 & 0,018 \\
\hline 45 & 0,065 & 0,02 \\
\hline 60 & 0,07 & 0,022 \\
\hline 75 & 0,079 & 0,023 \\
\hline 90 & 0,085 & 0,025 \\
\hline
\end{tabular}

Як видно з експериментальних даних, упродовж зберігання значення перекисного числа дослідних зразків вафель було меншим за контрольний у 3,4 раза, що свідчить про те, що добавка інуліну надає антиокислювальний вплив на жирову фазу начинки за рахунок зв'язування вільної вологи і зменшення гідролітичних процесів у жировій фазі. А також, ймовірно, за рахунок з'єднання полівалентних металів, які чинять інгібуючу дію на окислювальні ферменти.

Сучасні вимоги до якості та безпеки харчових продуктів і продовольчої сировини, строку придатності їх до споживання обумовлюють необхідність мікробіологічного контролю. Патогенні для організму людини штами бактерій Escherichia coli, Salmonella $є$ збудниками багатьох хвороб. Вони негативно впливають на органолептичні показники, викликають псування харчового продукту. При порушенні технологічних операцій, умов пакування, транспортування, зберігання борошняні кондитерські вироби можуть обсіменятися спорами мікроорганізмів. За сприятливих умов вони інтенсивно розмножуються. Чим вища загальна кількість мікроорганізмів (мезофільних аеробних і факультативно анаеробних), тим більша ймовірність існування шкідливої і патогенної мікрофлори.

Гігієнічні нормативи за мікробіологічними показниками для кондитерських виробів включають контроль чотирьох груп мікроорганізмів: санітарно-показові (КМАФАнМ, БГКП), умовно-патогенні (E. coli, St. aureus), патогенні (сальмонели), мікроорганізми псування (дріжджі, плісняві гриби).

Результати мікробіологічних показників досліджуваних зразків залежно від їх складу і умов зберігання наведені в табл. 3. 
Таблиця 3. Показники мікробіологічної безпеки вафель 3 начинкою

\begin{tabular}{|c|c|c|c|c|c|c|c|c|c|}
\hline \multirow{2}{*}{$\begin{array}{l}\text { Назва } \\
\text { зразків }\end{array}$} & \multicolumn{3}{|c|}{$\begin{array}{l}\text { МАФАнМ, КУО/г, не } \\
\text { більше }\end{array}$} & \multicolumn{3}{|c|}{ БГКП (коліформи) } & \multicolumn{3}{|c|}{$\begin{array}{c}\text { Дріжджі/пліснява, КУО/г, } \\
\text { не більше }\end{array}$} \\
\hline & Норма & 0 діб & 90 діб & Норма & 0 діб & 90 діб & Норма & 0 діб & 90 діб \\
\hline Зразок 1 & \multirow{4}{*}{$5 \cdot 10^{3}$} & $5 \cdot 10^{3}$ & $15 \cdot 10^{3}$ & \multirow{4}{*}{0,01} & - & - & \multirow{4}{*}{$1 \cdot 10^{2}$} & - & - \\
\hline Зразок 2 & & $5 \cdot 10^{3}$ & $5 \cdot 10^{3}$ & & - & - & & - & - \\
\hline Зразок 3 & & $5 \cdot 10^{3}$ & $4 \cdot 10^{3}$ & & - & - & & - & - \\
\hline Зразок 4 & & $5 \cdot 10^{3}$ & $3 \cdot 10^{3}$ & & - & - & & - & - \\
\hline
\end{tabular}

Зразки: $1-$ контроль; $2-10 \%$ інуліну і мікрокапсульовані біфідобактерії; $3-20 \%$ інуліну і мікрокапсульовані біфідобактерії; $4-30 \%$ інуліну і мікрокапсульовані біфідобактерії.

3 одержаних результатів видно, що початкова забрудненість усіх зразків однакова. Це пов'язано з використанням сировини, яка була обсіменена різними видами мікроорганізмів. Тривалість одержання жирової начинки складає 20 хвилин, процес відбувається в змішувачах або в збивальній машині, при цьому відбувається контакт з повітрям навколишнього середовища. Але показники КМАФАнМ через 90 діб зберігання у контрольного зразка підвищуються, а в дослідних зразків зі збільшенням масової частки інуліну зменшуються, що, ймовірно, можна пояснити антимікробною здатністю інуліну.

Була проведена оцінка зміни органолептичних показників контрольного $\mathrm{i}$ розробленого зразків вафель у процесі зберігання. В результаті можна зробити висновок про те, що дослідні вироби мають кращий смак і зовнішній вигляд порівняно з контрольним. У контрольного зразка під кінець строку зберігання почав 3'являтись мильний присмак, що свідчить про накопичення лауринової кислоти. Вафельний лист почав відставати від начинки, відбулося розшарування готового виробу.

На основі отриманих результатів розроблено проект нормативної документації на вафлі «Перлинка» (рецептури, технологічні інструкції, технічні умови). Ефективність розроблених рецептур і технологічних режимів виробництва вафель 3 жировими начинками функціонального призначення підтверджені дослідно-промисловими випробуваннями в умовах ТзОВ «Агробізнес» і ТОВ «Чарівний каравай».

Як показали виробничі випробування, розроблені вафельні вироби володіють відмінними споживчими властивостями, відрізняються високою якістю, мають приємний смак і функціональні властивості за рахунок вмісту фізіологічних функціональних інгредієнтів - пребіотику інуліну та пробіотику мікрокапсульованих біфідобактерій.

Технологія виробництва вафель із синбіотичним комплексом захищена патентом України № 118708 від 28.08.2017 «Композиція інгредієнтів для виробництва жирової начинки для вафель».

\section{Висновки}

Отже, комплекс експериментальних досліджень зміни показників якості вафельних виробів при зберіганні показав, що введення в рецептуру вафель синбіотичного комплексу забезпечує стабільну якість і сприяє кращій збереже- 
ності готових виробів протягом усього терміну зберігання. При цьому органолептичні показники виробів не змінюються, мінімізується мікробна контамінація продукції, не відбувається глибоких фізико-хімічних перетворень. Також введення синбіотичного комплексу дає змогу рекомендувати розроблені вироби як профілактичний засіб для людей, які страждають порушенням нормальної мікрофлори кишечника.

\section{Лiтература}

1. Матвеева Т.В., Корячкина С.Я. Мучные кондитерские изделия функционального назначения. Научные основы, технология, рецептуры. Санкт-Петербург: ГИОРД, 2016. $360 \mathrm{c}$.

2. Петрова Л.А., Ахмедова Т.П. Сахарное печенье с нетрадиционными добавками. Образование и наука без границ: фундаментальные и прикладные исследования. 2016. № 2. С. $73-78$.

3. Лазарева Т.Н., Корячкина С.Я., Лазарев П.Н. Разработка технологии пряничных изделий функционального назначения. Хлебобулочные, кондитерские и макаронные изделия XXI века: материалы IV Международной научно-практ. конференции, Краснодар, $17-19$ сентября 2015 г. С. 197-198.

4. Тарасенко I.B., Дорохович В.В., Іванов С.А. Вплив безглютенового борошна на вафельні вироби та перебіг технологічних процесів. Продовольчі ресурси. 2014. № 3. C. $36-39$.

5. Вафли с функциональными свойствами / И.Б. Красина и др.. Известия вузов. Пищевая технология. 2008. № 1. С. 41-42.

6. Дорохович А.М., Олексієнко Н.В. Класифікація борошняних кондитерських виробів за домінуючими чинниками, що визначають терміни їх зберігання. Наукові праці Украӥнського державного університету харчових технологій. 2000. № 6. С. 65-67.

7. Тарасенко Н.А., Красина И.Б., Денисенко Ю.Г. Диетические вафли с подсластителем из стевии. Известия вузов. Пищевая технология. 2010. № 2-3. С. 43 - 44.

8. Tarasenko N.A. Krasina I.B. The effect of pro- and prebiotics on the rheological properties of the model of structured disperse systems. American Journal of Biochemistry and Biotechnology. 2014. № 10 (2). P. 99-104. Doi: 10.3844/ajbbsp.2014.99.104.

9. Лозовая Т.М. Улучшение потребительских свойств вафель с использованием нетрадиционного сырья. Восточно-Европейский журнал передовых технологий. 2014. № 2/12. C. $108-113$.

10. Красина И.Б. Хашпяканц Б.О., Джахимова О.И. Кондитерские изделия для диетического питания Инновационные направления в пищевых технологиях: Материалы 5 Международной науч.-практ. конф., Пятигорск, 26-29 марта, 2012. Пятигорск, 2012. C. $210-212$.

11. Тарасенко Н.А. Влияние пищевых волокон на формирование потребительских свойств и сроки хранения сахарных вафель. Известия вузов. Пищевая технология. 2013. № 4. C. $81-82$.

12. Čukelj Nikolina, Putnik Predrag, Novotni Dubravka, Curic Duska Market potential of lignans and omega-3 functional cookies. Britich Food Journal. 2016. Vol. 118. № 3. P. 2420 2433. Doi: 10.1108/BFJ-03-2016-0117.

13. Коркач А.В. Разработка жировой начинки для вафельных изделий с использованием синбиотиков. Продовольственная безопасность в контексте новых идей и решений: Материалы Международной научно-практической конференции, г. Семей. Казахстан, 2017. Т. 2. С. 29-32.

14. Korkach H. Research intoeffect of the synbiotic complex on the quality of a fat filling for waffles. Eastern-European Journal of Enterprise Technologies. 2017. № 5/11(89). P. 18-25. Doi: 10.15587/1729-4061.2017.110598. 